\title{
NEUROMUSCULAR TRANSMISSION STUDIES IN HUMAN CHRONIC CHAGAS' DISEASE
}

\author{
MARCELA GARCIA ERRO* - O. GENOVESE * \\ J. CORREALE - R.E.P. SICA*
}

SUMMARY - An electrophysiological investigation of the state of the neuromuscular transmission (nmt) was carried out in 58 patients with the diagnosis of chronic Chagas' disease. On repetitive supramaximal nerve stimulation it was found that some patients did not show abnormalities, others had decremental muscle responses, others developed enhancement of the muscle evoked potential amplitudes, while some other patients combined both types of pathological responses. The findings suggest that some patients with chronic Chagas' disease develop impairement of nmt, though data obtained in this study do not give information about neither the type of impairement nor the localization (pre or postsynaptic, or both) of the damage.

\section{Estudio de la transmisioñ neuromuscular en la enfermedad de Chagas crónica humana.}

RESUMEN - Cincuenta y ocho pacientes con edades entre los 1 y 58 años, con diagnóstico de enfermedad de Chagas crónica fueron estudiados para evaluar la transmisión neuromuscular. Se estimuló en forma supramáxima el nervio cubital a nivel de muñeca, con registro de electrodos de superficie en hipotenar. Dicha estimulación se realizó a $3 \mathbf{H z}$ durante 2 segundos $y$ $10 \mathrm{~Hz}$ durante 1 segundo en condiciones basales, trás 4 mínutos de ejercicio mecánico, luego de 4 minutos de ejercicio mecánico mas isquemia y trás 2 rinutos de liberada ta isquemia. Se procedió a medir la amplitud del 3, 5, 6 y 10 potencial, que fueron expresados como variación porcentual con respecto al primero al que se le asignó un valor de 100\%. Treinta pacientes no evidenciaron diferencias con respecto a la curva obtenida en 20 sujetos controles, 4 mostraron una caida del potencial evocado muscular, 6 una caida del mismo cuando el estímulo se realizó a bajas frecuencias y un incremento cuanto el estímulo fue a altas frecuencias. En los restantes 18 pacientes se observó un incremento del pem. Estos hallazgos sugieren una posible alteración de la transmisión neuromuscular en algunos pacientes que han alcanzado el estadio crónico de la enfermedad de Chagas de probable localización pré y/o post-sináptica.

In the last years evidences have been accumulated demonstrating the involvemeni of the peripheral nervous system in the chronic state of human Chagas' disease 16-18, More recently, those findings received support from observations made in a mouse experimental model where the human features could almost be replicated 6.15 .

The present study has been designed as a complement of earlier investigations looking for the eventual involvement of the neuromuscular transmission (nmt) in patients who have reached the chronic state of the infection. A brief and limited account of these tindings has been given elsewhere 4.

* Sección Electroneurofisiologia Clínica, División Neurologia, Hospital Ramos Mejia; Departamento Medicina, Orientación Neurologia Facultad de Medicina, Universidad de Buenos Aires. 


\section{MATERIAL AND METHODS}

Patients - Altogether 58 patients were explored, 26 of them were females and 32 were males; their ages ranged between 19 and 58 years. None of them had received any treatment. related to the parasitic illness. The dilagnosis of Chagas' disease was done at the 'Instituto Nacional de Diagnostico e Investigacion de la Enfermedad de Chayas in Buenos Aires'. For these purposes three serological tests were employed namely: 1. Immunofluorescence; 2. complement fixation; 3. haemoagglutination. Only were aceppted for this investigation those patients who showed positiveness of, at the least, two tests. Coincidental causes of peripheral or central nervous system damage were eliminated from the study by rejecting patients over 60 years old 19 and those others who had had toxic, metabolic, genetic or infectious diseases able to develop neurological involvement. Controls - Twenty healthy and non selected people, with negative test for Chagas' disease, were employed as controls. Twelve of them 'were females and 8 were males. Their ages ranged between 20 and 45 years.

Technique - Electrodes: The recording electrode was a strip of silver foil, $4 \mathrm{~cm} l o n g$ and $0.5 \mathrm{~cm}$ wide, coated with electrode jelly and fixed with adhesive tapes at the skin of the hypothenar eminence overlying the end-plate area of the adductor digiti minimi muscle. The reference electrode, also a silver strip, was wrapped around the proximal phalanx of the index finger, while the earth electrode was situated at the dorsum of the hand. The stimulating electrode was a pair of silver discs, $0.8 \mathrm{~cm}$ in diameter, spaced two cm appart and mounted in a plastic holder which was fixed by a rubber band at the internal border of the ventral aspect of the wrist overlying the ulnar nerve. Once the electrodes were in position, isolated pulses were delivered from a Multistin stimulator and their intensity was gentIy increased until a maximal $M$ wave could be evoked at the hypothenar muscles. Thereafter, the stimulus intensity 'was made supramaximal by $20 \%$. Procedure: Supramaximal nerve repetitive stimulation was performed at two different frequencies, namely $3 \mathrm{~Hz}$ during 2 seconds and $10 \mathrm{~Hz}$ throughout 1 second. The time elapsing between both sets of stimulation was, at least, 15 seconds. The ambient temperature was mantained between 24 and 260 c. The procedure was repeated in the following conditions: a) with the muscles at rest; b) immediately after exercising the muscle during 4 minutes by delivering at the ulnar nerve a near-maximal stimulation at $3 \mathbf{H z}$ frequency; c) immediately after combining during also 4 minutes muscle exercise and muscle ischaemia developed by an over systolic pressure inflated cuff which was positioned at the upper arm; d) after two minutes of interrupting the muscle exercise and releasing the cuff 5. $M$ wave amplitude was measured pick to pick on the screen of a storage oscilloscope and the amplitudes of the $3 \mathrm{rd}$, 5th, 6th, and $10 \mathrm{th}$ potentials were referred as $\%$ of the first one.

\section{RESULTS}

Figure 1 summarizes the findings done in this study. From top to botton the first row shows the behaviour of control people. The second row comprises 30 patients whose response to repetitive stimulation did not differ from controls. The third row belongs to 4 patients who disclosed a decremental response of at least $15 \%$ at $3 \mathrm{~Hz}$ stimulation rate and $25 \%$ at $10 \mathrm{~Hz}$. The fourth row shows 6 patients who developed a decremental response at lower rates of stimulation and an incremental response at higher rates. Finally, the fifth row is composed by a group of 18 patients who showed an incremental response bigter than $60 \%$ at both rates of stimulation.

All patients tested were also submitted to maximal ulnar motor conduction velocity studies. None of them showed values below the lower control limit $(50 \mathrm{~m} / \mathrm{s})$.

\section{COMMENTS}

The findings in the present study point out to the end-plate as a structure which may be functionally impaired in some patients affected by chronic Chagas' disease. With the data obtained, it is hard to decide which is the type of impairement afflicting the neuromuscular transmission. Some patients had a decremental response, as happens with failures at the postsynaptic 14,21 or presynaptic sides $1,8,10,11,13,20,22$. Others disclosed enhancement of the amplitude of the muscle evoked potential as has been seen in disorders of the presynaptic side, though not to the extent which may be reached in the Eaton-Lambert syndrome 3,9 , while a third group had a combined response with decrement of the amplitude of the $M$ wave at low rates of stimulation and increment at higher rates. This last behaviour has also been described in failures of the nmt localized at the pre-synaptic level 2,7 . 

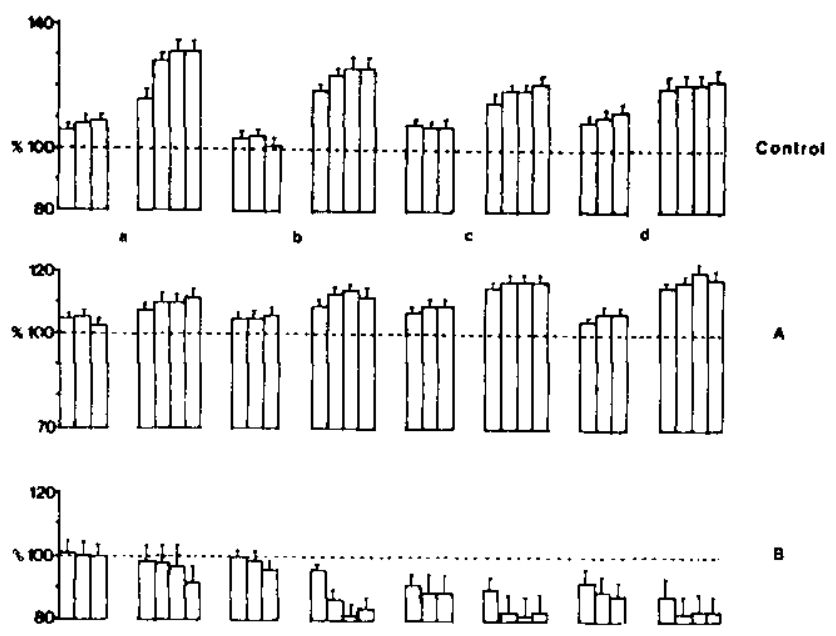

Fig. 1 - Percentage of increment and/or decrement of the amplitude of the third (left hand column on the $8 \mathrm{~Hz}$ and $10 \mathrm{~Hz}$ histograms), fifth (End column on both histograms), sixth (3rd column on both histograms) (tnd tenth (rigth hand column on both histograms, muscle evoked potential as compared with the first poten-

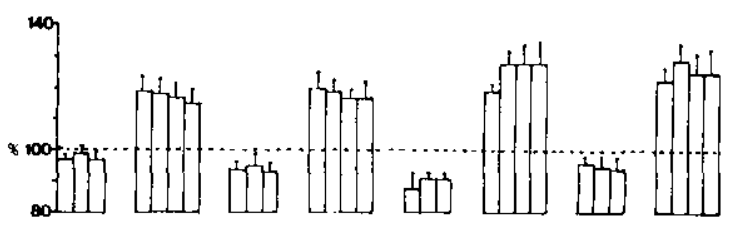
tial. (--), first potential amplitude expressed as 100\%. A: patients who do not differ from controls. B: patients with decremental response. $C: p a-$ tients with decremental response at loto stimulation rate and incremental response at higher stimulation rates. $D$ : patients with incremental response. $a$, basal condition. $b$, exercise. $c$, exercise cambined with ischaemia. $d$, \&' post

exercise and ischaemia.

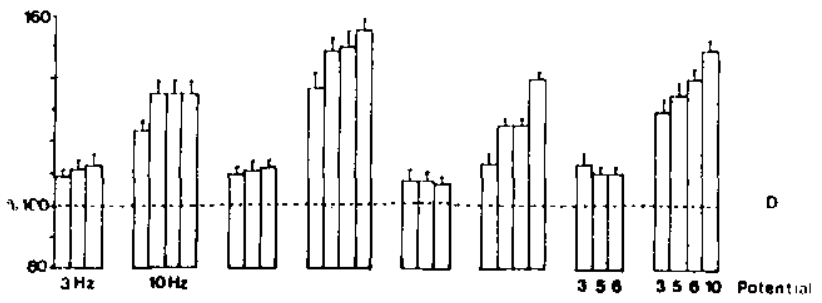

Based on present observations one is tempted to accept that both sides of the synapsis may be altered, either simultaneously or independently. In fact, Molina et al. 12 recently demonstrated damage of both sides of the end-plate in the mouse infected with trypomastigotes of the Tulahuen strain. However, in man neither we can decide whether this failure means a primary involvement of the end-plate nor if it may represent a damage developed as a consequence of the injury of the neural structures of the motor unit or of the muscle itself. The normal maximal motor conduction velocities found in every patient makes unlikely the possibility that harm of the large motor axons may play some role in the type of responses observed. Perhaps, deeper studies performed in the mouse experimental model 6 could shed more light on the pathogenesis of these features.

Acknowledgment - This investigation received financial support from the UNDP/World Bank/WHO Special Programme for Research and Training in Tropical Disease. It was also partially supported by a grant of CONICET.

\section{REFERENCES}

1. Baginsky RG - A case of peripheral polyneuropathy displayng myasthenic EMG patterns. Electroenceph Clin Neurophysiol 25:39\%, 1968.

2. DeJesus PV, Slater R, Spitz LK, Penn AS - Neuromuscular physiology of wound botulism. Arch Neurol 29:425, 1973.

3. Eaton LM, Lambert EH - Electromyography and electric stimulation of nerves in diseases of the motor unit. JAMA $163: 1117,1957$. 
4. Garcia Erro M, Genovese O, Losavio A, Correale J, Fumo T, Basso S, Lazzari J, Muchnik S, Gonzales Cappa S, Sica REP - Estudio de la transmision neuromuscular en la enfermedad de Chagas cronica: estudio electrofisiologico clinico $y$ experimental. XXVI Congreso Argentino Neurologico. San Miguel de Tucuman. Octubre, 1986.

5. Garcia Erro M. Sica REP, Losavio A, Muchnik S, Arroyo H - Tools to differentiate immunologic and non-immunologic myasthenia gravis in infancy. Neuropediatrics. In press.

6. Gonzalez Cappa SM, Sanz OP, Muller LA, Molina HA, Fernandez J, Rimoldi MT, Sica REP - Peripheral nervous system damage in experimental chronic Chagas' disease. Am J Trop Med Hyg 36:41, 1987.

7. Gutman L, Pratt L - Pathophysiologic aspects of human botulism. Arch Neurol $33: 175,1976$.

8. Hildebrand $\mathbf{J}$, Joffroy A, Coers $\mathbf{C}-$ Myoneural changes in experimental isoniazid neuropathy. Arch Neurol 19:60, 1968.

9. Lambert EH, Rook ED, Eaton LM - In Viets HR (ed): Myasthenia Gravis. Thomas, Springfield, 1961, pag. 362.

10. McComas AJ, Sica REP. Campbell M, Upton ARM - Functional compensation in partially denervated muscles. J Neurol Psychiat 34:453, 1971.

11. Metral $\mathbf{S}$, Tchernia $\mathrm{G}$, Tran $\mathrm{TL}$ - Preliminary observations on the effects of repetitive during neuropathies induced by vincristine. Electroencephalogr Clin Neurophysiol 30:368, 1971.

12. Molina HA, Cardoni RL, Rimoldi MT -- The neuromuscular pathology of experimental Chagas' disease. Neurol Sci $81: 287,1987$.

13. Mulder DW, Lambert EH, Eaton LM - Myasthenic syndrome in patients with amyotrophic lateral sclerosis. Neurology $9: 62 \bar{i}, 1959$.

14. Roberts DV, Wilson A - In Greene $R$ (ed) Myasthenia Gravis. Heinemann, London 1978, pag. 29.

15. Said G, Joskowicz M, Barreira AA, Eisen $H-$ Neuropathy associated with experinental Chagas' disease. Ann Neurol 18:676, 1985.

16. Sanz OP, Sica REP, Basso S, Fumo T - Compromiso del sistema nervioso periferico en la enfermedad de Chagras cronica. Medicina (Buenos Aires) 40 (supl 1):231, 1980.

17. Sica REP, Filipini D, Panizza M, Fumo T, Basso S, Lazzari J, Molina HA - Involvement of the peripheral sensory nervous system in human chronic Cragas' disease. Medicina (Buenos Aires) 46:662, 1986.

18. Sica REP, Sanz OF, Aristimuno GG, Basso S, Pagano MA, Taratuto A, Fumo T, Ratusnu AF, Colombi A - Muscle denervation in chronic Chagas disease. Medicina (Buenos Aires) $39: 579, \quad 1979$.

19. Sica REP, Sanz OP, Colombi A - The effects of ageing upon the human soleus muscle: an electrophysiological study. Medicina (Buenos Aires) 36:443, 1976.

20. Simpson JA - Disorders of neuromuscular transmission. Proc R Soc Med 59:993, 1966.

21. Stalberg E - Clinical electrophysiology in myasthenia gravis. J Neurol Neurosurg Psychiat $43: 622,1980$.

22. Thiele B, Stalberg E - Single fiber EMG findings in polyneuropathies of different etiology. J Neurol Neurosurg Psychiat 38:881, 1975. 